The University of Akron

\title{
IdeaExchange@UAkron
}

Proceedings from the Document Academy

University of Akron Press Managed

December 2014

\section{Identifying an Archetype: The Hipponion Tablet and Regional Variations in the Orphic Gold Lamellae}

Shellie A. Smith

Kent State University, ssmit115@kent.edu

Please take a moment to share how this work helps you through this survey. Your feedback will be important as we plan further development of our repository.

Follow this and additional works at: https://ideaexchange.uakron.edu/docam

Part of the Ancient History, Greek and Roman through Late Antiquity Commons, Classical Archaeology and Art History Commons, and the Classical Literature and Philology Commons

\section{Recommended Citation}

Smith, Shellie A. (2014) "Identifying an Archetype: The Hipponion Tablet and Regional Variations in the Orphic Gold Lamellae," Proceedings from the Document Academy: Vol. 1 : Iss. 1 , Article 8.

DOI: https://doi.org/10.35492/docam/1/1/8

Available at: https://ideaexchange.uakron.edu/docam/vol1/iss1/8

This Conference Proceeding is brought to you for free and open access by University of Akron Press Managed at IdeaExchange@UAkron, the institutional repository of The University of Akron in Akron, Ohio, USA. It has been accepted for inclusion in Proceedings from the Document Academy by an authorized administrator of

IdeaExchange@UAkron.For more information, please contact mjon@uakron.edu, uapress@uakron.edu. 
The Orphic lamellae are an enigma in the archaeological and epigraphic record. About forty of these incised gold tablets have been found buried in graves of believers throughout the Mediterranean, from a span of time ranging from the fifth century BCE to the third century CE. What these tablets are, who made them, and the beliefs they held have been a matter of conjecture since their discovery in the nineteenth century.

Since the analysis of the texts by Comparetti in 1879, the lamellae have been described as Orphic in origin, but what this means exactly is heatedly debated among scholars. One of the key problems in interpreting the gold lamellae is that there is no mention of them in literary sources from the periods that produced them, from approximately the fifth century BCE to the third century CE. The gold lamellae bear some resemblance to the defixiones, or lead curse tablets; both date to approximately the fifth century BCE. However, unlike the defixiones, the gold lamellae contain a narrative (Edmonds, 2004, p. 32). This narrative is indicative that it could have belonged to an initiation ritual that the deceased had completed, or was part of a funerary ritual. In addition, the archaeological context provides few clues, if the context was noted at time of excavation. There is also debate as to who utilized the tradition of the Orphic lamellae. Guthrie, for example, believed the lamellae to be a product of the lower classes, while other scholars like Musti believed the lamellae began with the aristocracy and worked its way down from them. The great variation in length of the lamellae indicate that initiates from different classes were followers, as scribes charged by the letter. Some of the lamellae, then, contain a full narrative, while others contain only the deceased's name and the word MYSTES- 'initiate.' While the diversity of followers can account for some of the variation, it cannot account for all of the variation, as some lamellae of similar length contain vastly different passages.

Edmonds, for example, rightly acknowledged the use of bricolage by the various authors of the lamellae to manipulate common sets of traditional elements for their own purposes, a theory also held by Graf and Johnston. The bricolage theory has many merits, as it explains the many variations in the tablets. As early as the fifth century BCE, Plato made mention of itinerant orpheotelestai, referring to them as 'con men (Graf, 2007, p. 70). These orpheotelestai were considered 'men of the book' and went door to door with their books of poetry, writings, and incantations, offering people the chance for salvation. What is under debate is the level of bricolage utilized by the orpheotelestai, as well as whether there were original sources for these itinerant priests to draw from.

In any case of bricolage, there is ultimately an original source of inspiration for the first bricoleur to draw upon when creating a new tradition. This original source of inspiration, in the instance of the lamellae, was a syncretic blend of mythologies and traditions surrounding a Dionysiac mystery tradition, blended 
with local customs and beliefs. The result is a widely varied belief system that spans several centuries and covers all of Greece, including the islands, and Italy. The lamellae are referred to as 'Orphic' because of their references to Persephone, Dionysus/Bacchus, and other deities associated with Dionysiac cult. However, many scholars have fallen into the trap of finding references to the dismemberment myth of Dionysus Zagreus by the Titans in the lamellae before there were references made in the literature. ${ }^{1}$

There are a number of limitations in studying the gold lamellae. First, and most importantly, the exact number of lamellae in existence is unknown. There are graves that have yet to be excavated, and numerous more that have been looted throughout the centuries. In the lamellae that have been discovered and preserved, some are missing portions of text, making interpretation and analysis difficult. In addition, many early excavations kept poor records, so the context of several of the lamellae has been lost. This context is invaluable to the interpretation of the lamellae. Things such as the type of burial (inhumation, cremation) and grave (cist, tumulus), and the type of grave goods indicate many key things about the Orphic followers that utilized the lamellae, including social class and gender. Contemporary information about the lamellae does not exist, so scholars must make an educated guess based on other evidence, including literary and archaeological, as to the true meaning and function of the lamellae. There are also limitations to the bricoleur theory as it is applied by scholars. Most importantly, while modern scholarship readily accounts for the vast differences in the lamellae, it does not so easily account for their similarities. Indeed, many scholars refuse to acknowledge that two lamellae that have the exact same symbolism could have come from the same source, chalking the similarities up to 'coincidence' and a 'loose belief in eschatological doctrines.' ${ }^{2}$ However, one vital question has not been addressed by scholars, namely, why, despite the great variety in space, time, and content, did they consistently utilize gold tablets in a funerary context? The

\footnotetext{
${ }^{1}$ For an excellent discussion of the extant literature regarding the Dionysus Zagreus myth by century, see Torjussen, Metamorphoses of Myth: A Study of the 'Orphic' Gold Tablets and the Derveni Papyrus, chapter 3. Torjussen argues that the myth of the dismemberment of Dionysus Zagreus was unknown in the ancient sources before the second century to first century BCE at the earliest. He also Argues against the notion of 'original sin,' of mankind having to suffer for the Titans' treatment of Dionysus, claiming it to be a modern invention by Neoplatonists and early modern scholars influenced by Christian thought. The notion of 'original sin' is not without precedent in ancient Greek mythology; it is found in the myth of Prometheus, for example, which is told by Hesiod. However, the Titans, while viewed as the progenitors of the human race and many other forms of life in several myths, were not viewed negatively, but rather as generators of life. In this regard, The wild, primitive force of the Titans stand in contrast to the civilizing nature of the Olympian gods; Dionysus, who has aspects of both wildness and civility, serves as a bridge between the two worlds.

${ }^{2}$ This is the main thesis of Torjussen in Metamorphoses of Myth.
} 
similarities between the gold lamellae illustrate a more cohesive tradition than previously believed, as shown through exemplars found in the lamellae. While a true textual criticism of the initiation ritual cannot at this time be conducted, due to the disparity of documents, analyzing the lamellae via their similarities, within their respective contexts, sheds some light on how the texts might have been transmitted over time.

The longest extant lamella serves as an archetype for many of the gold lamellae, as it contains the most complete symbolism. Dating to about $400 \mathrm{BCE}$, this lamella was found in Hipponion (modern Vibo Valentia), Italy, in the region of Magna Graecia. There are several formulaic phrases that are found in other lamellae throughout the Mediterranean, indicating that it was used as a model in other areas. The formulaic phrases include references to the white cypress tree, drinking from the guarded Lake of Memory rather than the lake of Forgetfulness, and referring to the initiate as a 'child of earth and starry sky:'

"This grave belongs to Mnemosyne, for the time when he shall die, on the right side of the well-fitted house of Hades is a spring, and close to this stands a shining cypress: Around this place the descending souls cool themselves. Do not approach this spring. But proceed to the lake of Mnemosyne with cold water flowing forth: There are Guardians here: and they will ask you with shrewd speech what you are looking for in the darkness of deadly Hades. Say: "I am a son of Earth and starry Heaven: and I am parched with thirst and perishing: But give me to drink from the cold water from Mnemosyne's lake." And they will show you to the Chthonian king: and give you to drink from Mnemosyne's lake: And then you will walk on the holy path of the many, on which also other renowned mystai and bakkhoi walk."

It is significant that the Hipponion tablet mentions bakkhoi, worshippers of Dionysus, in the last line. Indeed, it is one of the only lamellae to directly mention Dionysus/Bacchus or his followers. The last line of the text illustrates that the initiate (as shown by the term mystai) expects to achieve a blessed state of existence after death because of his initiated status. It is generally accepted by scholars to be an excerpt from a ritual that the deceased participated in; the future tense found in line one indicating that death has not yet occurred, shows that it belonged to an initiation ritual rather than a funerary rite performed at the gravesite of the deceased (Torjussen, 2008, p. 157).

\footnotetext{
${ }^{3}$ Hipponion, ca 400 BCE, translated by Torjussen.
} 
Anomalies in the Hipponion tablet indicate that it came from an earlier source. The narrative of the Hipponion tablet has several grammatical errors, which Edmonds argues signifies that it originated from an older, oral source (Edmonds, 2004, p. 32). However, Giannobile, Sergio, and Jordan argue that the anomalies found in the text are indicative that the Hipponion tablet was copied from a now lost original, composed in epic-Ionic, which had somehow been damaged (Giannobile, 2008, p. 288). The text, written in Doric, has several words that appear corrupt or are inscribed irregularly; many of the errors occur in clusters, indicating that the model the scribe had was damaged and he had to supply the missing pieces by memory. The anomalies found in the Hipponion text illustrate that, despite the arguments of scholars like Torjussen, the beliefs and rituals that the orpheotelestai utilized in their holy books were more similar than previously thought, and that in many instances a tradition was handed down from one priest to another. Indeed, the Edict of Ptolemy IV Philopator from the third century BCE supports this notion. ${ }^{4}$

The lamella found at Petelia (first part of the fourth century BCE) is very similar to that found at Hipponion. While some of the text is missing, the two are similar enough to have come from one source, as they contain many of the same formulaic phrases:

"On the left side in the House of Hades you shall find a spring, and standing by it a white cypress: do not approach this spring. But you shall find another by Mnemosyne's lake cold water flowing forth: but there are guards before it. Say: "I am a child of Earth and starry Heaven: however my race is of heaven: this you know yourselves. I dry up and perish from thirst: but give me quickly the cold water flowing forth from the lake of Mnemosyne." And they themselves will give you to drink from the sacred spring and thereafter you shall be lord amongst heroes ........this. $[\ldots \ldots \ldots \ldots . . . \ldots \ldots . . . .$. around. (Torjussen, 2008, pp. 259-260)"

The lamellae show varying levels of bricolage depending on what most concerned the deceased (Edmonds, 2004, p. 36). For example, the role of Mnemosyne is prevalent in the regions having a strong Pythagorean influence, notably in Pythagorean centers of Magna Graecia. Pythagoreanism had a strong influence in

\footnotetext{
${ }^{4}$ The Edict of Ptolemy IV Philopator calls for each 'Priest of Dionysus' to bring a sealed copy of his holy books to the capital and register them, along with a list of who initiated each priest, going back three generations. Ptolemy IV was known as an avid worshiper of Dionysus, so many scholars believe this to be a move to legitimize the worship of Dionysus in Egypt. However, what is unclear is whether the edict refers to the Dionysiac Mysteries or the Orphic Mysteries, as the Orphic tradition has been referred to in ancient literature as a 'tradition of the book.'
} 
Magna Graecia until the fifth century BCE, when it began to be persecuted and the cult went into hiding. The inclusion of drinking from the spring of Mnemosyne has important implications particularly from a Pythagorean perspective, as implies a possible belief in reincarnation, allowing the initiate to remember the current life in preparation for the next incarnation. ${ }^{5}$ It is also significant that these tablets have been found in the Greek colonies, rather than the mainland. When placed in this context, the use of giving directions to an elevated state in the afterlife serves as an allegory to returning to the motherland. Given the distance to be traveled to experience the blessings that initiation at Eleusis offered, it was only a matter of time before someone capitalized on the situation, offering an alternative for those displaced from their home. In all, approximately twelve of the lamellae follow some of the patterns set forth by the Hipponion tablet; these are found in the areas surrounding Hipponion, in Italy, and as far away as Crete.

The tablet from Thessalia, in central Greece, dates to the second half of the $4^{\text {th }}$ century BCE, based on the bronze cinerary urn in which it was discovered and the lettering. This is the first of the abbreviated texts that actually show a sort of dialogue between the deceased and various entities he encounters, indicating that it was a part of a ritual. The entities encountered include the guardians of the Lake of Mnemosyne and the Lake itself:

"I am parched with thirst and I perish. But drink of me, the everflowing spring, Where on the right side is a shining cypress. Who are you? Where are you from? I am a son of Earth and starry Heaven. But my race is of Heaven alone (Torjussen, 2008, p. 284)."

A group of lamellae dating to the 3rd-2nd centuries BCE were discovered in Eleutherna, Mylopotamos, and Sfakaki in Crete. These lamellae all have similar symbolism, indicating they come from the same source. These lamellae are virtually identical to the Thessalia tablet. This is compelling evidence that such phrases were part of rituals utilized by the orpheotelestai, and that texts such as the Hipponion tablet contained a more complete version of the ritual. A separate one was discovered in Eleutherna dating to the 3rd century BCE, which does not follow the same symbolism. This lamella instead contains the password 'chairein.' This could indicate a separate bricoleur operating in the area at that time.

When looking at the Cretan lamellae it is important to consider their context, just as it is vital to consider the context of the lamellae from Magna Graecia. Crete

\footnotetext{
${ }^{5}$ See Edmonds pp. 53-55 for a full discussion of the role of Mnemosyne in the longer lamellae.
} 
held a special place in the archaic and classical period for producing great heroes and religious leaders. It was both located in the middle of nowhere and the center of the Mediterranean, on the periphery of mainland Greece, and viewed as a 'wonderland' of sorts because of its real and perceived antiquity (Tzifopoulos, 2010, pp. 178-179). According to Diodorus, the rites that Eleusis kept secret, Crete made available to all of its citizens. Diodorus utilized Epimenides, the Cretan theologos par excellence of the archaic period, as one of his main sources, which lends credence to the Cretan claim to provenance of mystery cults in Greece. The Cretans were also known for orgiones, mystery rites of both Demeter and Dionysus (Tzifopoulos, 2010, p. 158).

One of the great 'Cretan Paradoxes' is the concept of a god who is eternal yet dies and is reborn. While this concept is applied to gods of fertility in other parts of Greece, in Crete it is found in the figure of Zeus Kretagenes. The notion that the head of the Olympians was subject to the cycles of nature was foreign to the rest of Greece; thus, Zeus Kretagenes was adapted as the chthonic Dionysus. Indeed, the two traditions are quite similar, as the Cretan tradition holds that Zeus had a tomb, variously at Ida and Dikte, whereas Dionysus had a tomb at Delphi (Tzifopoulos, 2010, p. 169).

But what, then, of some of the other lamellae? Do they follow some sort of pattern as well, or do they merely contain random snippets of text? Indeed, many of the lamellae do follow a pattern, indicating that they were created by itinerant orpheotelestai. By analyzing the grouping of certain lamellae, it is clear that, in many instances, one bricoleur was responsible for the creation of the lamellae in each area. It is also clear which orpheotelestai utilized the same rituals and holy books' at a later time. This illustrates a continuity in the tradition developed by the original bricoleur; whether later orpheotelestai traveled to other areas, creating their own traditions and books as they went, or the tradition was strictly followed, with rituals and books copied verbatim cannot be deciphered solely by looking at the lamellae.

The tablets found at Thurii date to approximately a ten year period around 350 BCE. The lamellae were discovered in tumulus tombs at Timpone Piccolo and Timpone Grande. All of the burials were inhumations, with the exception of Thurii 1 at Timpone Grande, which was a partial cremation. All of the deceased were buried facing east, perhaps in ritual significance. The Thurii tablets contain a distinct ritual formula that links them together, indicating they come from the same tradition. This similarity, coupled with the fact that they all occurred within a ten year period, provide compelling evidence that the lamellae were all created by the same bricoleur/orpheotelestai. 
Pure I come out of the pure, Queen of the Underworld, And both Eukles and Eubouleus and all the other immortal Gods: For I too maintain to be of your blessed kind, But Fate subdued me, and all the other immortal gods and the starflunged thunderbolt.

And I have flown out of the grievous, troublesome circle, I have passed with swift feet to the desired wreath, I have entered under the bosom of the lady of the house, the Queen of the Underworld, I have passed with swift feet from the desired wreath Happy and Blessed, you shall become god, the opposite of mortal. A kid I have fallen into milk. ${ }^{6}$

The most striking feature of these lamellae is the 'immersion in milk' formula, which Torjussen and other scholars rightly argue illustrate part of an initiation ritual. Milk is a powerful symbol of a soul's purity and its potential for rebirth. Milk is linked to the stars and heavens, notably the Milky Way, in literature from as early as the seventh century BCE. 'Righteous souls' reside among the stars in the Milky Way after death rather than going to Hades. This sort of belief is not without precedent, as it was not uncommon for heroes to be turned into stars or constellations after death as a reward by the gods. Many scholars, including Torjussen, argue against Dieterich's literal interpretation of the passage in an initiatory ritual context, ${ }^{7}$ akin to a baptism rite, despite the use of similar rituals being used by other mystery traditions, including the cult of Mithras.

Also significant in the Thurii tablets is the opening phrase 'Pure I come out of the pure.' This purity refers to the initiated status of the deceased, and the pure life lead by the initiate, which separates initiates from the rest of the dead. This first line is found not only in the Thurii tablets but in other tablets, showing that ritual purity was important to the people using these lamellae.

The Thurii tablets were the inspiration for other lamellae in the region. The Rome tablet has elements of both the Thurii tablets and the Hipponion tablet:

Pure she come out of the pure, Queen of the Underworld Eukles and Eubouleus, fair child of Zeus: I have

\footnotetext{
${ }^{6}$ Thurii 3, c. 360 BCE, found in Timpone Piccolo. Translation by Stian Sundell Torjussen.

${ }^{7}$ Dieterich, and later Harrison, argued for a literal interpretation of the Thurii texts, including a physical baptism in milk and jumping in and out of wreaths. The immersion in milk is a tantalizing theory, as it has parallels in other mystery traditions, but the jumping in and out of wreaths should not be interpreted literally. Rather, I agree with Torjussen that the wreaths correspond with the 'grievous circle' mentioned in line 5 of Thurii 3, which is an allusion to reincarnation. For a full discussion, see Torjussen, Metamorphoses of Myth, p. 161.
} 
The gift of Mnemosyne, famous among men.

Caecilia Secundina, forward, by law, to become godlike. ${ }^{8}$

The first line is verbatim from the Thurii tablets, bringing a five hundred year continuity to the lamellae. The mention of Mnemosyne, on the other hand, hearkens back to the mnemonic formulas of the Hipponion tablet and those influenced by it. The fact that the Rome tablet has elements of both the Thurii and Hipponion has intriguing implications, particularly given the tablets late date. It is entirely possible that the Thurii and Hipponion tablets are related to the same cult, and that different portions of the initiation ritual were emphasized in each area for the lamellae. It is also possible that an orpheotelestai somehow had access to the books from both traditions, and melded the two traditions together when creating the Rome tablet. At this point it is a matter of conjecture.

In the western Peloponnese, near Elis, another regional bricoleur has been identified, dating to the Hellenistic period. Several gold lamellae have been discovered throughout the Elean region. One in particular was found in Daphniotissa, in 1981, bearing the name 'Palatha.' Other grave goods were found in the grave, including several clay pots (one of which had pine resin and the remains of beeswax), a bronze mirror, and a gold ring (Torjussen, 2008a, p. 151). Other gold tablets were found throughout the region, all from cist graves dating to the early Hellenistic period. Three tablets were found in Aigion; they were shaped like a laurel or olive leaf, a leaf, and an almond, and inscribed with the words 'Mystes,' 'Dexilaos Mystas' and 'Philon Mystas,' respectively. The first inscription is a generic one designating the deceased as an initiate of a mystery tradition, while the other two name the deceased specifically, and then identify them as initiates. Two more lamellae were found at Elis; one was in the shape of a myrtle leaf with the name 'Philemena' inscribed on it, and the other was of an undisclosed shape, with the name 'Euxena' inscribed on it.

There are a number of common features with all of these lamellae that indicate that they could be the work of one bricoleur. The deceased that were buried with the lamellae were all buried in cist graves. The lamellae were all cut into a leaf shape, with the exception of one. These are all indicative of Dionysiac worship, especially since Dionysus was revered in this region. Indeed, according to Pausanias, Dionysus was revered above all the gods and was worshiped at the Thuia by the Eleans (Pausanias 6.26, 1-2). Torjussen believes this to be the work of itinerant priests and rightly notes the fact that the uniformity in this region is rare when compared to other regions, strengthening the likelihood that this is the work of one such priest (Torjussen, 2008a, p. 152).

\footnotetext{
${ }^{8}$ Rome, c. 250 CE. Translation by Stian Sundell Torjussen.
} 
An intriguing find near Magoula Mati, close to Pherai, might shed some illumination on how an initiate of the Eleusinian Mysteries borrowed what he learned from this initiation and applied it to the Orphic tradition. A gold, leaf shaped lamella was discovered in a tomb in 1904, but not analyzed and published until 2007. The text has some problems, which scholars have debated, and has been reconstructed in this way:

"Send me to the bands of initiates: I am able to perform the [holy/beautiful] rites of Demeter Chthonia and Mountain Mother."

The original publishers of the lamella, Parker and Stamatopoulou, rightly believe the lamella to be the work of an itinerant priest. However, it is curious that they do not acknowledge the possibility that this priest was an initiate of Eleusis, and this is why Demeter Chthonia was mentioned, rather than Bacchus or Dionysus. One significant aspect of the lamella is the phrase 'able to perform the [holy/beautiful] rites,' rather than merely having 'done,' 'shown,' and 'said' things: the dromena, deiknumena, and legomena that were a key part of the oath taken by initiates at Eleusis. This phrase could indicate the burial of a priest, which is the argument of Ferrari and Prauscello (Ferrari, 2007, p. 195). However, Furley disregards this theory, because of its peculiarity in describing the initiate's qualifications for being allowed into the company of mystai; rather than stating that the deceased has performed the secret rites, in this instance the deceased can perform the secret rites (Furley, 2009, p. 32). Another, more fascinating thought is the concept of grades of initiation in local cults of the Orphic tradition. This is supported by the plural form of 'rites,' 'orgia.' Ferrari and Prauscello argue that the plural use of the word indicates two initiations in the rites of the same cult, rather than initiations into two different cults. The fact that two initiations were mentioned is another indication that the initiate participated in the rites at Eleusis, as he might have chosen to mirror the Lesser and Greater Mysteries of the Eleusinian cult.

What, then, about the unifying use of gold tablets in funerary context? What inspired the original bricoleurs to utilize tablets of gold to illustrate an initiate's status, as opposed to another type of symbola? In analyzing this notion, there are some very tantalizing ideas. As was already mentioned, the lamellae do bear some similarities to defixiones which were found throughout the Greco-Roman world, and date to at least the fifth century BCE. The curses were written on thin sheets of lead, and often buried in graveyards, since they invoked chthonic deities to help fulfill the goal inscribed by its creator. However, the use of a heavy material such as lead would not be suitable for a religion seeking to set its members apart as being divine and pure, as it would readily be associated with curse tablets. A more precious, pure material was needed. Zuntz states that gold was chosen to symbolize life due to its brightness, just as lead was chosen due to its darkness, 
and that the lamellae were a conscious development in response to defixiones (Edmonds, 2004, p. 32). Indeed, gold was chosen by the creator of the enigmatic lamella MS 5236, an ephesia grammata dating to the sixth century BCE from Asia Minor. This lamella is unique, as it is the only protective amulet known to have been created in gold; protective amulets have been found thus far only in lead.

The lamellae are a fascinating aspect of Orphism, one that might never fully be understood due to the fact that, other than a number of thin gold sheets found in graves scattered throughout the Mediterranean, no mention is made of them in the ancient sources. This lack of context makes it especially difficult to interpret the lamellae. Even without the religio-cultural context, however, scholars can piece together valuable information about the lamellae, those who created them, and those whose beliefs led them to be buried with them. In document studies, searching for the origins of documents, as well as how successive documents relate to the exemplar, is vital, particularly in the realm of textual criticism. This search is admittedly more difficult in the field of Classical Studies than with later documents, as so many documents have either been destroyed or have yet to be found. With the lamellae in particular, studying their connections as documents is also difficult, due to the lack of literary context and our limited knowledge of how the texts traveled over time. Thus, much of what we know about the texts and how the ideas were transmitted are largely up to conjecture. However, the lamellae contain clues that indicate a tradition in which an archetypal document was copied from priest to priest. Corruptions in the earliest lamella from Hipponion illustrate this tradition of being copied, suggesting that it will someday be possible to recreate the original rituals used by the priests.

The bricolage theory explains the number of variations between the different lamellae and myths surrounding the deities in Orphism. However, the bricoleur theory does raise some questions. Many scholars, including Torjussen, believe that itinerant orpheotelestai each had their own traditions, and were only loosely linked by loose eschatological beliefs in a blessed afterlife. The orpheotelestai drew upon established pan-hellenic mythology and wove that with local customs when creating traditions unique to each space and time. A study such as this raises many questions. What were in these holy books that the orpheotelestai utilized? Is there an exemplar that later priests copied, containing initiation rituals and other holy rites? Finally, many scholars miss one key piece of evidence: why did each of these priests choose to utilize gold lamellae in their traditions consistently, despite the differences with the texts? The consistent use of gold lamellae in a burial context, as well as the use of narrative in the longer texts, illustrate there is more uniformity than previously believed, and that in many instances, the later examples find their origins in earlier texts. 


\section{References}

Bernabe, Alberto. 'Some Thoughts About the 'New' Gold Tablet from Pherai.' Zeitschrift für Papyrologie und Epigraphik, Bd. 166 (2008), pp. 53-58.

Edmonds III, Radcliffe G. Myths of the Underworld Journey: Plato, Aristophanes, and the 'Orphic' Gold Tablets. New York: Cambridge University Press, 2004.

Ferrari, Franco and Prauscello, Lucia. "Demeter Chthonia and the Mountain Mother in a New Gold Tablet from Magoula Mati." Zeitschrift für Papyrologie und Epigraphik, Bd. 162 (2007), pp. 193-202.

Furley, William. “'Admit Me to the Company of Initiates:' Suggestions on the Text of the Recently (Re)discovered Gold Funerary Lamella from Pherai." Zeitschrift für Papyrologie und Epigraphik, Bd. 170 (2009), pp. 31-34.

Giannobile, Sergio and Jordan, D. R. "On the Text of the Hipponium Tablet." Greek, Roman, and Byzantine Studies 48 (2008), 287-294.

Graf, Fritz and Iles Johnston, Sarah. Ritual Texts for the Afterlife: Orpheus and the Bacchic Gold Tablets. New York: Routledge, 2007.

Torjussen, Stian Sundell. "An Inscribed Gold Olive Leaf from Daphniotissa, near Elis." Zeitschrift für Papyrologie und Epigraphik Bd 166 (2008), pp. 151152.

Torjussen, Stian Sundell. Metamorphoses of Myth: A Study of the 'Orphic' Gold Tablets and the Derveni Papyrus. University of Tromso, 2008.

Tzifopoulos, Yannis. Paradise Earned: The Bacchic-Orphic Gold Lamellae of Crete. Cambridge: Harvard University Press Center for Hellenic Studies, 2010. 